DOI: 10.34015/2523-4552.2019.3.04

УдК 343:848

Левченко Л. Л., доктор історичних наук, доцент, директор Державного архіву Миколаївської області e-mail: loralewch@gmail.com ORCID ID: 0000-0001-9097-7373

\title{
МИКОЛАЇВСЬКИЙ ПІКЛУВАЛЬНИЙ ПРО ТЮРМИ КОМІТЕТ ЯК ОРГАН УПРАВЛІННЯ ТЮРЕМНИМ ГОСПОДАРСТВОМ ТА ОПІКИ НАД В'ЯЗНЯМИ
}

На підставі документів архівних фондів досліджується історія та діяльності Миколаївського піклувального про тюрми комітету. Визначено його роль та вплив на стан справ у миколаївських в'язницях. Діяльність Миколаївського піклувального про тюрми комітету, незважаючи на недоліки, у цілому справляла позитивний вплив на стан тюремних закладів у Миколаєві.

Ключові слова: Миколаӥвський піклувальний про тюрми комітет; каторжна тюрма; міська тюрма; виправне арештантське відділення.

Исследуется история и деятельность Николаевского попечительского о тюрьмах комитета. Обнаруженные о нем сведения проверяются на основании документов других архивных фондов. Деятельность Николаевского попечительского о тюрьмах комитета, несмотря на недостатки, в целом оказывала положительное влияние на состояние тюремных заведений в Николаеве. Фактически комитет поддерживал людей в тюрьмах, напоминая им, что они все еще остаются членами общества.

Ключевые слова: Николаевский попечительный о тюрьмах комитет; каторжная тюрьма; городская тюрьма; исправительное арестантское отделения.

Постановка проблеми. Історія піклувальних про тюрми комітетів на території України, підконтрольній Російській імперії у XIX - на початку XX ст. набуває особливої актуальності на сучасному етапі реформування пенітенціарної системи в Україні, коли йдеться про потреби встановлення громадського контролю над пенітенціарними закладами й прозорість їх діяльності. Утворення та діяльність піклувальних про тюрми комітетів, прикладом яких $є$ Миколаївський піклувальний про тюрми комітет, були надзвичайним і нехарактерним для царського режиму Російської імперії явищем, оскільки фактично громадськість (хоча то й були елітні прошарки) отримала доступ до інформації про стан справ у тюрмах і здійснювала контроль над ними.

Аналіз останніх досліджень i публікацій. На жаль, цій темі прис- 
вячено не так уже й багато праць. Зокрема від радянських часів лишилося одне, хоча й грунтовне, дослідження Михайла Гернета «История царской тюрьмы» у 5 томах, у якому узагальнено й систематизовано величезного обсягу фактичний матеріал 3 історії царських в'язниць. Утім, він не вбачав у тюремній справі позитивної ролі піклувальних комітетів [1]. У незалежній Україні, зокрема в Миколаєві, були опубліковані монографія Юрія Гузенка [2], у якій побіжно розглянуто діяльність Миколаївського піклувального про тюрми комітету, а також статті Володимира Щукіна [3], котрий висвітлив історію створення й реформування піклувальних про тюрми комітетів на теренах Російської імперії, та Марини Мельник [4], яка приділила увагу фінансовим питанням у діяльності Миколаївського піклувального про тюрми комітету. Вікторія Пальченкова підготувала монографію (2013 р.) [5] та захистила дисертацію (2014р.) [6; 7; 8] про громадський контроль над пенітенціарною системою України у IX - на початку XXI ст. Автор розглядає патронат пенітенціарної системи з історико-правових позицій. Одна зі статей ученої присвячена формам, методам і змісту діяльності Чернігівського комітету Товариства піклувального про тюрми. На відміну від Михайла Гернета, Вікторія Пальченкова обстоює позитивну роль та ефективність впливу Чернігівського комітету на пенітенціарну систему губернії. Дослідниця далека від ідеалізації його діяльності й указує на труднощі в роботі комітету, недосконалість законодавства, суттєві розбіжності між державними органами управління пенітенціарними закладами та правлінням комітету [9].
Постановка завдання. Мета статті полягає у висвітленні діяльності Миколаївського піклувального про тюрми комітету, його ролі й фактичного впливу на стан справ у миколаївських в'язницях.

Виклад основного матеріалу. у 1805 р. Миколаїв, заснований як суднобудівна верф, став центром Миколаївського і Севастопольського військового губернаторства, що було спеціально створене з метою забезпечення розвитку Чорноморського військово-морського флоту. У місті розташувалося Управління Чорноморського флоту й всі флотські структури. Протягом першої половини XIX ст. місто фактично було фортецею. У Миколаєві функціонував Аудиторіат, тобто вищий військовоморський суд, що займався вирішенням карних справ військових, які служили на флоті.

На жаль, у державному архіві Миколаївської області збереглися лише окремі справи Аудиторіату, так само вони розпорошені по різних фондах й у Центральному державному архіві військово-морського флоту Російської федерації. У Миколаєві також діяв Олексіївський морський острог (будівля збереглася до наших днів на вулиці 2-й Слобідській), гауптвахта, а у Севастополі - плавуча в'язниця (на військовому судні). У 30-х роках XIX ст. на ділянці землі, яка належала відомому миколаївському купцю Бухтєєву, збудували міську тюрму.

У другій половині XIX - на початку XX ст. у Миколаєві функціонували: 1) гауптвахта для нижніх чинів морського відомства (у будинку міського магістрату); 2) виправне арештантське відділення на 600 осіб, розташоване на вулиці Католицькій, 
буд. $1 / 3$; 3) Олексіївський морський острог (вулиця 2-га Слобідська); 4) міська тюрма № 1 (так звана Бухтєєвська) на 400 осіб; 5) каторжна (водночас пересильна) в'язниця (під № 2) на 600 осіб на Лагерному полі, для якої перебудували стару будівлю Артилерійського училища, а також споруджено ще кілька корпусів і будинок для персоналу.

Після поразки Російської імперії у Кримській війні (1853-1856 pp.) й тимчасового занепаду суднобудування, було ухвалено рішення відкрити Миколаїв для закордонної торгівлі: з 1862 р. розпочав роботу Миколаївський міжнародний торговий порт, швидких темпів набував експорт зернових. Місто перестало бути цитаделлю. Саме тоді, на початку 60-х років XIX ст., у Миколаєві все більше стали поширюватися гуманістичні ідеї, у т. ч. під їх впливом настоятель Миколаївського адміралтейського собору протоієрей Лаврентій Михайловський ініціював заснування у місті піклувального про тюрми комітету, архівний фонд якого під № 209 нині зберігається в Державному архіві Миколаївської області. До його створення благодійна справа в Миколаєві, у т. ч. й опіка над в'язнями перебувала в руках жіночого благодійного товариства, фундаторкою якого була дружина Головного командира Чорноморського флоту та портів і Миколаївського військового губернатора адмірала Михайла Лазарева, Катерина. Згодом цю справу продовжила Емілія фон Глазенап та інші дружини військових губернаторів і градоначальників. У подальшому піклувальний про тюрми комітет і жіноче благодійне товариство паралельно здійснювали опіку над миколаївськими тюрмами, однак жіноче товариство не мало владних повноважень, якими був наділений піклувальний комітет.

Ідея встановлення громадської опіки над тюремними закладами зародилася ще за часів імператриці Катерини II, котра під впливом італійського юриста, автора трактату «Про злочини й покарання» (1764), Чезаре Беккаріа збиралася реформувати карне законодавство й тюремну систему Російської імперії. Хоча згодом Катерина II відмовилася від модних ідей періоду «освіченого абсолютизму», однак iї онук імператор Олександр I підхопив ці ідеї. Він перебував під впливом англійського філантропа Вальтера Веннінга, члена Лондонського товариства покращення тюремного порядку. Веннінг приїхав до Петербурга 1817 р. й був спершу представлений Міністру духовних справ князю Олександру Голіцину, а потім й самому імператору. Саме його доповідь стала основою для розробки статуту «Піклувального товариства про тюрми», офіційно затвердженого 1821 р. За задумом Венінга мета товариства полягала в гуманізації пенітенціарної системи, воно здійснювало постійний нагляд за в'язнями, наставляло їх в правилах благочестя, а згодом поступово перебрало на себе всі питання управління й утримання місць ув'язнення.

У 1825 р. товариство отримало права контролю над коштами, що виділялися з міських і земських зборів на опалення та освітлення в'язниць. У 1827-1829 рр. та у 1837 р. під контроль товариства перейшли фінансові асигнування, що виділялися 3 державного бюджету на продовольство, одяг і лікування арештантів. 31827 р. товариство контролювало придбання продуктів та якість 
приготування харчів у в'язницях. Члени товариства відвідували в'язниці й займалися розподілом пожертвувань. Результатом відвідин членами товариства тюрем також стала заборона в 1829 р. передавати в'язням спиртні напої.

У 1844 р. указом Сенату діяльність товариства була поширена на всі губернії Російської імперії, де засновувалися комітети товариства. На той час в імперії вже функціонувало 49 губернських піклувальних про тюрми комітетів та 217 повітових. Відтак, поступово тюремне господарство було вилучено з відання поліції й передано комітетам. Держава у такий спосіб фактично зняла з себе відповідальність за утримання в'язнів і забезпечення їх усім необхідним. У 1841 р. президентом товариства став начальник III відділення канцелярії імператора Олександр Бенкендорф, який почав реформування, маючи на меті встановлення державного контролю над діяльністю товариства.

7 листопада 1851 р. схвалено новий статут товариства, а 31855 р. його підпорядкували Міністерству внутрішніх справ. До головних напрямів діяльності товариства за новим статутом належали: внутрішнє облаштування тюрем і ремонт, забезпечення в'язнів одягом, білизною, взуттям і всім необхідним, нагляд за розміщенням і харчуванням в'язнів, піклування про тюремні лікарні та лікування в'язнів, виправлення їх моралі, пересилання по етапу, вирішення питань про долю в'язнів, наприклад про скорочення строків покарання, викуп ув'язнених за борги тощо. До складу товариства на загальнодержавному рівні та у губерніях входили високопоставлені й заможні особи (на місцях комітети товариства очолювали віцепрезиденти, до складу входили до 20 директорів у залежності від розмірів губернії, повіту чи міста), котрі мали вплив у суспільстві й жертвували значного обсягу кошти на тюремну справу. Володимир Щукін порахував, що за 60 років функціонування товариства його члени пожертвували понад 21 мільйон рублів на потреби тюрем і в'язнів [3]. Звичайно, що з думкою цих людей доводилося рахуватися консервативним поліцейським і тюремним чиновникам. Це справило позитивний вплив на тюремну систему, зробивши їі більш відкрию й прозорою. Однак, у Російської імперії, яка сама по собі була «тюрмою народів», така діяльність була не надто популярною, отже 1893 р. товариство підпало під критику консервативних кіл влади й суспільства. $\mathrm{y}$ результаті його позбавили деяких функцій.

У Миколаєві першим віцепрезидентом піклувального про тюрми комітету був Головний командир Чорноморського флоту та портів і Миколаївський військовий губернатор адмірал Богдан фон Глазенап. До першого складу правління належало 19 директорів [11]. Звіт товариства за 1869 р. надає уявлення про стан тюремної системи у Миколаєві. На той час миколаївське арештантське відділення було до неможливості тісним. Морське відомство віддало під розміщення арештантів, затриманих за рішенням мирових суддів, один 3 відомчих будинків. Тож в арештантському відділенні поліції та поліцейських частин міста утримувалися лише ті особи, справи яких розглядалися прокурорами та судовими слідчими. Спорудження нової 
будівлі для міської тюрми унеможливлювалося тим, що місто всі кошти спрямувало на будівництво нової міської лікарні. Отже, у старій будівлі міської тюрми зробили незначний ремонт, на який витратили всього 50 руб. Важливі злочинці утримувалися в морському острозі та гауптвахті морського відомства.

Одяг i взуття пересильним в'язням видавалися з фондів Херсонського губернського правління. Інші в'язні носили власний одяг і лише найнужденніші іноді забезпечувалися окремими речами. Кошти на харчування виділяла Херсонська казенна палата. Розподілом коштів державного бюджету займалася Миколаївська міська поліція. Церков у миколаївських тюрмах не було, однак у 1869 р. в'язням роздали книжки духовного змісту, а осіб, котрі перебували на гауптвахті водили на сповідь до Миколаївського адміралтейського собору. В'язнів лікували у спеціальному відділенні Миколаївської міської лікарні. У тюрмах не було майстерень, в'язні також не залучалися на роботи поза тюремними стінами, оскільки не було достатньої кількості наглядачів для їх охорони. Через відсутність вільних земельних ділянок не було можливості розводити садки та городи [12].

Після заснування Миколаївського піклувального про тюрми комітету справи пішли на краще. Комітет збирав кошти на харчування в'язнів, у раціоні яких з'явилося м'ясо, сало, овочі, крупи, білий хліб, молоко, яйця, цукор [13]. Наприклад, у 1914 р. на харчування здорових в'язнів було витрачено 10909 руб., хворих 4503 руб. [14]. Комітет враховував, що окремі в'язні не могли харчуватися за загальним столом через хворо- би й видавав їм гроші для купівлі потрібних продуктів. Зокрема, в архівному фонді піклувального комітету містяться документи про задоволення прохання Федора Карпова, котрий через хворобу шлунку потребував дієтичного харчування [15]. При Миколаївській каторжній в'язниці насадили садок і розвели город [16].

Виділялися кошти на надання в'язням перукарських послуг (стрижку й гоління). Ще 1899 р. в'язнів лікували у арештантському відділенні Миколаївської міської лікарні [17], однак при миколаївських тюрмах уже працювали фельдшери. 3 архівних документів очевидно, що тюремні лікарні збудували 1910 р. Для в'язнів, котрих передбачалося там лікувати, навіть приготували нову постільну білизну та одяг [18]. 1910 р. на посаду постійної акушерки була призначена Лідія Лимаренко, яка до того впродовж 10 років на безоплатній основі надавала лікарські послуги в жіночому відділенні Миколаївської міської тюрми. При лікарні міської тюрми відкрилася аптека, при чому було прийнято рішення, що завідування аптекою може бути довірено в'язню [19].

1899 р. духовним наставником у Миколаївській міській тюрмі став священник Петро Зеньчевський [20]. У 1916 р. священник Андронік Донський пожертвував церкві при Миколаївській міській тюрмі приладдя та книги [21].

У Миколаївській міській тюрмі працювала школа. Станом на 1916 р. заняття там велися щодня по 4 години, крім святкових днів [22]. В'язнів навчали читати та писати [23]. Для них за рахунок комітету було придбано зошити, олівці, бук- 
варі. На той час у міській тюрмі вже працювала бібліотека, з якої до наших днів дійшов каталог книг, які читали в'язні. Серед авторів, книги яких пропонувалися в'язням, були В. Гаршин, Ч. Діккенс, О. Дюма, Жуль Верн, Г. Лессінг, Ж. Мольєр, А. Чехов та інші поети та письменники [24]. У бібліотеці організовувалися читання, дискусії, зустрічі зі священником [25].

Архівні документи свідчать, що Миколаївський піклувальний про тюрми комітет мав вплив щодо вирішення питання про помилування та дострокове звільненя. Зокрема, 1910 р. комітет прийняв рішення скоротити втричі строк покарання Веклі Новицькій, котрій на той час виповнилося 65 років. Вона спокутувала провину в тюрмі через вбивство власної служниці й поводила себе бездоганно [26].

Без дозволу представників комітету в Миколаївській міській тюрмі не застосовувалися тілесні покарання. Коли в'язень Мойсей Фельдман лаяв керівництво тюрми нецензурними словами й погрожував зарізати заступника начальника тюрми, його лише закрили в карцері, але щоб застосувати до нього тілесні покарання начальник тюрми був змушений звернутися за дозволом до Миколаївського військового губернатора (1899 р.) [27].

Також у Миколаєві діяло Товариство опіки над особами, звільненими з в'язниць, кошти якому видавав Миколаївський піклувальний про тюрми комітет. Зокрема, у липні 1909 р. було виділено 200 руб. для надання матеріальної допомоги колишнім в'язням [28].

Позаяк висвітлений вище стан миколаївських тюремних закладів за архівним фондом Миколаївського піклувального про тюрми комітету демонструє дещо комфортні умови тюремного ув'язнення, виникає потреба перевірити його за документами інших архівних фондів. У Державному архіві Миколаївської області зберігаються документи Миколаївської каторжної в'язниці № 2 за період 1881-1920 рр. (Фонд № 250), Миколаївської тюремної інспекції за 1868-1919 pр. (Фонд № 251), Миколаївської тимчасової тюремнобудівельної комісії за 1907-1917 pр. (Фонд № 444), Піклування над Миколаївським виправним арештантським відділенням за 1903-1917 рр. (№ 445). Документи цих фондів надають ширше уявлення про стан справ у миколаївських тюремних закладах.

Наприклад, у документах Миколаївської тюремної інспекції виявлено відомості про освячення новозбудованої церкви Святого Апостола і Першомученика Архидіякона Стефана при Миколаївській міській в'язниці у вересні 1911 р. [29], що підтверджує дійсність піклування про духовний стан ув'язнених. Разом з цим, виявлено лист Миколаївського градоначальника контрадмірала Олександра Мязговського від 14 серпня 1912 р., направлений до Головного тюремного управління, про стан тюремних церков, шкіл $\mathrm{i}$ бібліотек миколаївських тюрем. Мязговський критикував директорів Миколаївського піклувального про тюрми комітету, які були банкірами, купцями, власниками підприємств, за недостатню увагу до своїх обов'язків. Він уважав, що директори комітету займаються власними справами й не зацікавлені у релігійно-моральному вихованні в'язнів і 
розвитку шкільного навчання в тюрмах. Контрадмірал писав, що покладатися можна лише на священників тюремного відомства, але їх не вистачає для забезпечення всіх тюрем і їхня заробітна платня надто низька. Мязговський указував, що в міській тюрмі заняття в школі вів один із в'язнів. Далі він підсумовував: «Крім цього поставити добре шкільну справу в міській в'язниці дуже важко 3 огляду на постійно перемінний склад тюремного населення [!]. Друга причина, яка утрудняє постановку шкільної справи в місцях позбавлення волі на більш міцних засадах полягає в нестачі для цього коштів. Добровільні ж пожертвування зовсім не надходять на цю справу, а тим часом на придбання книг, навчальних посібників і приладдя, в яких відчувається нестача, засобів немає, а тому не виявилося навіть можливим придбати чарівні ліхтарі для каторжної і міської в'язниць. Це ж стосується питання про ненадання комітетом звітів про діяльність на додаток до звітів щодо обсягу економічного й піклувального капіталів, то такі ніколи не надавалися по Миколаївському градоначальству, зважаючи на вищевикладені причини про склад директорів» [30]. Відтак, діяльність Миколаївського піклувального про тюрми комітету не була вже й такою бездоганною.

В архівному фонді Миколаївської тюремної інспекції також є свідчення про вжиття заходів для покращення санітарно-гігієнічного стану в'язниць. У червні 1911 р. в арештантському відділенні встановлено патентований кип'ятильник-стерилізатор ємкістю 32 відра, виготовлений одеським машинобудівним заводом «С. М. Литовський» [31].
У Миколаївському виправному арештантському відділенні в напівпідвальному секторі було відремонтовано каналізацію, оскільки через несправність труб рідина просочувалася в стіни камер. Важливою справою було упорядкування роботи асенізаційного обозу. У 1911 р. в каторжній тюрмі утримувалося 802 особи, у міській - 484, у виправному арештантському відділенні - 1061, разом 2347. Щоденно з кожної тюрми вивозилося по 10 бочок (кожна по 40-50 відер) нечистот. Вивіз нечистот здійснювався приватними особами, які постійно піднімали ціну. Врешті замість асигнованих за кошторисом 30 коп. за бочку ціна досягла 98 коп. Вирішено було створити власний тюремний асенізаційний обоз, у якому б працювали самі арештанти. Було обраховано кількість бочок, вартість утримання коней, визначений порядок роботи арештантів, задіяних на асенізації. У Миколаївському виправному арештантському відділенні для працюючих в асенізаційному обозі були виділені окремі камери, їх одяг після роботи піддавався дезінфекції, частіше дезінфікувалися й білилися їхні камери. У колі питань, які розглядались у зв'язку 3 організацією асенізаційного обозу, було й забезпечення тюремних закладів водою. Каторжна тюрма за період 31 січня по 1 листопада 1911 р. використала 711800 відер води (2,9 відра на одну людину), міська - 486738 (3,39), виправне арештантське відділення - 929197 (2,95). Звітність свідчить, що встановлена норма води відповідала фактичним потребам. У 1909 р. закінчено будівництво нового корпусу виправного арештантського відділення на 384 арештанти, у 1910 р. - лікарень при 
каторжній та міській тюрмах, у 1911 р. - корпусу Управління міської в'язниці та майстерень на 200 працюючих в'язнів, у 1912 р. - корпусу для наглядачів міської тюрми. Асенізаційний обоз обслуговував не лише безпосередньо тюрми, тюремні лікарні та інші тюремні заклади, а й звичайні цивільні установи міста [32].

В архіві збереглися цікаві документи про роботу тюремних майстерень. Так, станом на 1910-1911 pр. у Миколаївській каторжній тюрмі працювали столярна, кравецька, взуттєва, слюсарна, палітурна та миловарна майстерні, обладнані всіма необхідними верстатами [33]. У виправному арештантському відділенні працювали столярна, ткацька, швецька, кравецька, оббивочна, палітурна, картонажна, ковальська, слюсарна, корзинна майстерні. На виконувані арештантами за замовленнями роботи були чітко визначені ціни. Наприклад, виготовлення шафи для одягу з вільхи коштувало 5 руб., з ясеню - 6 руб, полірованого комоду з вільхи - 4 руб., з ясеню 6 руб., сундука - 4 руб. Пошиття лакованих чобіт оцінювалося в 1 руб. 20 коп., чоловічих черевиків - від 50 до 65 коп., жіночих - від 50 до 70 коп., чоловічих туфель - від 30 до 60 коп., жіночих - від 40 до 75 коп., дитячих чобіт - від 25 до 70 коп., костюму звичайного - 5 руб., модного пальто - 8 руб., простого - 5 руб., дитячого пальто - 3 руб. Оббивка плюшем дивану середньої величини коштувала 3 руб., матрацу двоспального пружинного - 60 коп., кушетки 1 руб. 20 коп. Книжку сап'янову із золотим тисненням оправляли за ціну від 15 до 40 коп., теки коленкорові виготовляли залежно від розміру за ціну від 20 до 50 коп., на більш витончені палітурні роботи встановлювалися договірні ціни [34].

У 1911 р. Миколаївська тюремна інспекція 3 метою збільшення тюремного заробітку запропонувала відкрити при Миколаївській каторжній в'язниці друкарню. Ця пропозиція була схвалена вищим тюремним керівництвом, оскільки вважалося, що підприємство зможе щорічно приймати замовлень на 130 тис. руб. У друкарні виготовлялися бланки, афіші, рекламні проспекти, етикетки, наукові брошури, звіти різних відомств, адрес-календарі, прейскуранти тощо [35]. Крім майстерень, в'язні, переважно арештантського відділення та міської тюрми, працювали на різних зовнішніх роботах у місті, в порту, на залізниці.

Ще цікавішими $\epsilon$ документи про витрачання зароблених в'язнями коштів. Так, у 1910 р. ув'язнені виправного арештантського відділення відпрацювали на різних роботах 130581 людино/добу, заробили 24886 руб., з яких витрачено на придбання матеріалів 1185 руб., на виплати в'язням згідно зі Ст.359 «Устава о содержащихся под. стражей» (1909 р.) 7110 руб., внесено в дохід казни 8295 руб., перераховано в дохід місць утримання 8295 руб., виплачено арештантам за господарські роботи 501 руб., витрачено на ремонт знарядь праці 708 руб., залишок 7084 руб. В'язні Миколаївської міської тюрми відпрацювали в 1910 р. 30803 людино/доби, заробили 6067 руб., 3 яких виплачено в'язням згідно зі Ст. 361 «Устава о содержащихся под. стражей» 588 руб., та згідно зі Ст.359 2034 руб., внесено в дохід казни 1526 руб., перераховано в дохід місць ув'язнення 1918 руб., виплачено 
арештантам за господарські роботи 145 руб., сплачено за ремонт знарядь праці 75 руб., залишок 1697 руб. В'язні Миколаївської каторжної тюрми в цьому ж році відпрацювали в майстернях i внутрішніх роботах 51426 людино/годин, заробили 15592 руб., з яких на придбання матеріалів було витрачено 4248 руб., на виплати в'язням відповідно до Ст. 359 - 1132 руб., внесено в дохід казни - 5103 руб., перераховано в дохід місць ув'язнення 5103 руб., виплачено в'язням за господарські роботи 367 руб., сплачено за ремонт знарядь праці 864 руб., залишок 3871 руб. [36]. Таким чином, ув'язнений виправного арештантського відділення за відпрацьовану добу отримував на руки 0,058 коп. (тобто менше третини від заробленого), міської тюрми - 0,089 коп. (менше половини від заробленого), каторжної тюрми - 0,029 коп. (лише десяту частину від заробленого). Частина коштів також витрачалася на утримання асенізаційного обозу, великі виплати із зароблених в'язнями коштів здійснювалися в якості винагороди службовцям Миколаївської тюремної інспекції (від 255 руб. діловоду до 710 руб. тюремному інспекторові) й трохи менші суми (від 15 до 50 руб.) виплачувалися канцелярському персоналу тюрем. Ці підрахунки підтверджують думку, висловлену дослідником С. В. Шебалковим, про дешевизну праці в'язнів у Російській імперії. Він також дійшов висновку, що через це, а також через умови утримання та ставлення персоналу тюремних закладів до в'язнів в'язнична система Російської імперії не досягала ефективності у виправленні покараних за різні злочини й правопорушення [37].
Проте, існували й інші причини: у своєму бажанні заробити на в'язнях і використати їх фактично безкоштовну працю на будь-чию користь, тюремне начальство забувало про прагнення людини до свободи й психологію особи, здатної на порушення законів, як офіційних, так і людських. Яскравим прикладом $\epsilon$ таємне листування між Миколаївським виправним арештантським відділенням i Миколаївською тюремною інспекцією, у якому йдеться про моральний клімат і поведінку в'язнів. У відділенні в будь-який час можна було придбати горілку, в арештантів чи в наглядачів (пляшка коштувала 50 коп.). Горілку в бочках у тюрми також доставляв асенізаційний обоз. Ув'язнені, котрі працювали в майстернях, часто використовували свої власні інструменти, самі приймали замовлення від замовників і встановлювали ціни на роботи, за свій кошт купували матеріали й завжди мали на руках гроші. Вони самі купували продукти й готували харчі прямо в майстернях. У відділенні процвітали азартні ігри.

Тож, наполягання виконуючого обов'язки Миколаївського тюремного інспектора графа Муравйова на різкому збільшенні доходу від арештантських робіт, який 31 січня до 26 лютого 1912 р. складав 12672 руб., у начальника відділення викликало побоювання. Він писав: «Незважаючи на весь ризик з мого боку випустити таку недисципліновану масу арештантів в кількості 500 чоловік на зовнішні роботи, де немає карцерів, і бажаючи виконати його наказ, я просив його сіятельства дозволу зшити гамівну сорочку, на що і отримав дозвіл» [38]. Така сорочка зв'язувала людину «кач- 
кою», так щоб не можна було стати на ноги.

Чи робилося це на практиці важко сказати, оскільки архівний фонд № 251 рясніє справами про втечі в'язнів під час перебування на зовнішніх роботах, при чому у більшості випадків цим втечам сприяли самі тюремні наглядачі або втечі сталися через їх халатність.

Наприклад, у липні 1911 p. 10 в'язнів арештантського відділення у супроводі двох наглядачів були направлені на розвантаження каменю в каботажну гавань морського порту. Під вивантаженням стояло 5 вагонів, до кожного з них спрямували двох в'язнів. Вагони мали виходи з обох боків, але наглядачі спостерігали за роботами лише з однієї сторони. Нарешті наглядач Прокоп Карташов вирішив обійти вагони з другого боку й побачив відкриті двері одного з них. Увійшовши до вагону, він зустрів там в'язня Іллю Макарашвілі, який сидів і палив. Карташов запитав, де інший в'язень - Єгор Алтухов. Макарашвілі відповів, що той, імовірно, пішов у якийсь інший вагон, теж палити. Під час дізнання Карташов стверджував, що втечі Алтухова сприяла стороння особа, котра відкрила двері вагону з другого боку. Однак, Макарашвілі заявив, що двері вагонів відкривалися легко й без сторонньої допомоги. Обидва наглядачі були засуджені за халатність [39], хоча в дійсності вони фізично не могли забезпечити нагляд за 10 особами.

Недостатня кількість охоронців при виведенні засуджених на зовнішні роботи була констатована в серпні 1911 р., коли на залізницю для вивантаження шпал було направлено 50 в'язнів арештантського відді- лення й лише 5 наглядачів. Тоді під час роботи втік в'язень на ім'я Зелінський [40]. У цьому ж місяці зі столярної майстерні арештантського відділення, перевдягнувшись у цивільний одяг, втік в'язень Работніцький. Під час його втечі наглядач в іншій майстерні видавав ковалям вугілля [41]. У вересні 1911 р. ув'язнені арештантського відділення Сохинський-Малярчук і Дверницький виконували ремонтні роботи в оселі священника Серафима Купчевського. Господиня запросила їх на обід, після якого попросила Дверницького поклеїти вікна, а СохинськогоМалярчука виправити піч. Наглядачі після обіду займалися власними справами. Коли вони нарешті вирішили перевірити підопічних, від одного $з$ них лишився лише арештантський одяг. Він переодягнувся в цивільний піджак, переліз через огорожу й втік. Наглядачів Петра Ковальського й Георгія Туряка засудили за невиконання обов'язків і пособництво в'язням при втечі [42]. Ув'язнені арештантського відділення часто використовувалися й на городніх роботах поза межами відділення. Вони залишалися там на ночівлю, спали в пристосованих приміщеннях. У липні 1912 р. партія 8 в'язнів охоронялася лише двома наглядачами, які вночі залишили свій пост. Пилипу Буянову для втечі навіть не довелося вдаватися до хитрощів. Він просто встав о третій ранку й пішов. Федора Алабіна самого відпустили виправляти природну потребу в очерет і він не повернувся. За їх втечу був засуджений наглядач Діомід Куцак [43].

Отже, побіжний огляд документів архівного фонду Миколаївської тюремної інспекції демонструє недоліки в роботі Миколаївського піклу- 
вального про тюрми комітету, погляд на тюрму як на велике комерційне підприємство як з боку тюремного керівництва, так і з боку самих в'язнів (як це не дивно звучить!), халатність і схильність до зловживань персоналу тюрем.

У січні 1917 р. Головне тюремне управління визначило Миколаївське виправне арештантське відділення закладом для утримання каторжних арештантів. На той час у Миколаєві функціонувало три в'язниці: каторжна, виправне арештантське відділення і міська тюрма. Особи, котрі утримувалися у виправному відділенні, використовувалися на зовнішніх роботах, вони вже одержували компенсацію за свою працю по 3 руб. за день (причиною збільшення платні була інфляція) і на їх працю, як і раніше, був великий попит містян.

Утриманці міської тюрми, що охоронялася тюремною вартою, в основному працювали всередині закладу над виконанням нескладних замовлень для армії або на зовнішніх роботах. Каторжна в'язниця охоронялася військовим караулом і в ній утримувалися каторжани з Кавказу та віддалених внутрішніх губерній Росії. Наявність такого тюремного закладу в Миколаєві ускладнювала ситуацію, особливо з часу оголошення воєнного стану, адже то вже був період Першої світової війни й поширення революційних настроїв серед населення. Каторжна в'язниця вимагала не лише посиленого військового караулу, а й яскравого нічного освітлення ззовні. Миколаївський градоначальник Андрій Покровський писав про те, що авіація ворога може легко виявити таку ілюмінацію. Він уважав, що однієї каторжної в'язниці для Миколаєва вже достатньо й виступив категорично проти реорганізації виправного арештантського відділення на другу каторжну в'язницю. Він наполягав, що такі заклади у воєнний час мають розміщуватися у віддалених внутрішніх губерніях, а не в таких прикордонних містах як Миколаїв. Йому вдалося добитися скасування рішення Головного тюремного управління, що було підтверджено листом від Штабу флоту 6 лютого 1917 р. [44].

3 початком Лютневої революції, 5 березня 1917 р. 3 Миколаївської каторжної в'язниці були звільнені політичні в'язні. При чому питання про те, кого з них слід уважати політичними розглядалося міською владою разом із представниками промислових підприємств міста [45]. Було прийнято рішення стосовно 24 осіб.

Карні злочинці Миколаївської каторжної в'язниці вимагали також негайно їх звільнити. 9 березня 1917 р. начальник в'язниці повідомляв про можливість бунту. У тюрмі лишилися на той час лише рецидивісти, засуджені за багаторазові вбивства, грабунки, підпали тощо. Ніякі заклики до роботи, молитви й дотримання порядку не мали на них впливу. Адміністрація в'язниці опинилася під загрозою, начальник вимагав вислати посилений військовий караул, а також просив представників Комітету громадської безпеки та Ради робітничих і військових депутатів прибути для переговорів із в'язнями [46]. Згодом у цій в'язниці поряд з кримінальниками опинилися міський голова Микола Леонтович, який напередодні революції очолював Миколаївський піклувальний про тюрми комітет, гласні Миколаївської міської думи, миколаївський 
градоначальник Олександр Мязговський (розстріляний більшовиками разом із дружиною 1919 р.), останній Миколаївський градоначальник імперського періоду і Морський міністр Української Держави Гетьмана Скоропадського Андрій Покровський (випущений під підписку, втік) та інші миколаївці.

З 1917 р. Миколаївський піклувальний про тюрми комітет припинив свою діяльність. Ніхто не наглядав за ситуацією в тюрмах і вони перетворилися з органів «покарання i виправлення» на органи «покарання й репресій». Від захоплення влади більшовиками діяльність таких закладів як Миколаївський піклувальний про тюрми комітет більше не простежується.

Висновки. Діяльність Миколаївського піклувального про тюрми комітету, незважаючи на недоліки, у цілому справляла позитивний вплив на стан тюремних закладів у Миколаєві. Фактично комітет підтримував людей у тюрмах, нагадуючи їм, що вони все ще залишаються членами суспільства. Церква, школа, бібліотека, навчання, читання, спільна робо- та в саду та на городі, в майстернях і ззовні в місті хоча б трохи сприяли соціалізації в'язнів і підтриманню їх зв'язків із зовнішнім світом, до життя в якому вони мали повернутися. Держава, залишивши тюрми на майже повному госпрозрахунку, спонукала тюремну адміністрацію до використання в'язнів на примусових роботах із метою отримання прибутку як для самофінансування тюремних закладів, так і для фінансової підтримки тюремного чиновництва. А втім, будь-яка праця сприяла перевихованню. Навряд чи в'язні мали б сидіти без діла в камерах і чекати на благодійництво. Працюючи, вони хоч трохи заробляли на своє прожиття. Однак, тюремна адміністрація зловживала своїм службовим становищем. Використовуючи низько оплачуваний труд в'язнів вона перетворювала тюрми на комерційні підприємства з примусовою працею. У такий спосіб тюремні начальники зводили нанівець зусилля комітету щодо перевиховання й реабілітації в'язнів й перешкоджали гуманізації пенітенціарної системи Російської імперії.

\section{Список використаних джерел}

1. Гернет М. Н. (1951-1954). История царской тюрьмы. В 5-ти т. Москва : Государственное издательство юридической литературы. 1951-1954.

2. Гузенко Ю. Становлення і діяльність громадських благодійних об'єднань на Півдні України в другій половині XIX - на початку XX ст. (на матеріалах Херсонської губернії). Миколаїв : Іліон. 2006. 240 с.

3. Щукин В. Общественная благотворительность и попечительство в пенитенциарных учреждениях Российской империи. Наукові праці Нащіонального університету «Одеська юридична академія». 2012. Т. 11. С. 456-463.

4. Мельник М. Діяльність Миколаївського піклувального про в'язниці комітету. URL: http//:www.mk.archives.gov.ua (дата звернення: 30.05.2019).

5. Пальченкова В. М. Трансформація громадського контролю за виконанням покарань: історико-правовий аналіз. Запоріжжя : Акцент, 2013. 523 с. 
6. Пальченкова В. М. Витоки та еволюція громадського контролю за пенітенціарною системою України (IX - початок XXI ст.) : автореф. дис. ... д-ра юрид. наук / Класич. приват. ун-т. Запоріжжя. 2014. 40 с.

7. Пальченкова, В. М. Трансформація правової регламентації діяльності Товариства піклувального про тюрми (1819-1919 рр.) Науковий вісник Дніпропетровського державного університету внутрішніх справ. 2012. № 4. С. 73-82.

8. Пальченкова В. М. Ідея та практика тюремного патронажу в Російській імперії. Держава та регіони. Серія: Право. 2013. № 1. С. 29-33.

9. Пальченкова В. М. Чернігівський комітет товариства піклувального про тюрми: основні форми, методи та зміст діяльності. Держава та регіони. Серія: Право. 2012. № 2. С. 188-193.

10. Церенюк О.М. Роль комітетів Товариства піклувального про тюрми у розвитку пенітенціарної системи Наддніпрянської України XIX ст. Проблеми історії України XIX - початку XX cm. 2002. 5. С. 169-183.

11. Державний архів Миколаївської області (далі - ДАМО). Ф. 209. Оп. 2. Спр. 1. Арк. 29-30.

12. ДАМО. Ф. 209. Оп. 2. Спр. 1. Арк. 44-47.

13. ДАМО. Ф.209. Оп. 2. Спр. 2. Спр. 15. Арк. 21, 57; Спр. 21. Арк. 22; Спр. 47. Арк. 7, 15, 56, 115.

14. ДАМО. Ф. 209. Оп. 2. Спр. 43. Арк. 4.

15. ДАМО. Ф. 209. Оп. 2. Спр. 48. Арк. 31-32.

16. ДАМО. Ф. 209. Оп. 2. Спр. 38. Арк. 8.

17. ДАМО. Ф. 209. Оп. 2. Спр. 4. Арк. 20.

18. ДАМО. Ф. 209. Оп. 2. Спр. 25. Арк. 8, 12, 14, 18-19.

19. ДАМО. Ф. 209. Оп. 2. Спр. 32. Арк. 2, 2зв.

20. ДАМО. Ф. 209. Оп. 2. Спр. 4. Арк. 16.

21. ДАМО. Ф. 209. Оп. 2. Спр. 38. Арк. 30.

22. ДАМО. Ф. 209. Оп. 2. Спр. 45. Арк. 13-14.

23. ДАМО. Ф. 209. Оп. 2. Спр. 38. Арк. 6-7.

24. ДАМО. Ф. 209. Оп. 2. Спр. 38. Арк. 17-20.

25. ДАМО. Ф. 209. Оп. 2. Спр. 45. Арк. 14-15.

26. ДАМО. Ф. 209. Оп. 2. Спр. 35. Арк. 7.

27. ДАМО. Ф. 209. Оп. 2. Спр. 4. Арк. 7.

28. ДАМО. Ф. 209. Оп. 2. Спр. 23. Арк. 8.

29. ДАМО. Ф. 251. Оп. 2. Спр. 71. Арк. 7.

30. ДАМО. Ф. 251. Оп. 2. Спр. 39. Арк. 65-67.

31. ДАМО. Ф. 251. Оп. 2. Спр. 63. Арк. 6.

32. ДАМО. Ф. 251. Оп. 2. Спр. 68. Арк. 4-46.

33. ДАМО. Ф. 251. Оп. 2. Спр. 86. Арк. 3.

34. ДАМО. Ф. 251. Оп. 2. Спр. 76. Арк. 7-8.

35. ДАМО. Ф. 251. Оп. 2. Спр. 48. Арк. 46-47.

36. ДАМО. Ф. 251. Оп. 2. Спр. 29. Арк. 30зв. - 31.

37. Шебалков С. В. Тюрьма в России в конце XIX - начале XX века и ее исправительное значение. Ученые записки Казанского университета: гуманитарные науки. 2014. Кн. 3. Т. 156. С. 111-120.

38. ДАМО. Ф. 251. Оп. 2. Спр. 109. Арк. 28-28зв.

39. ДАМО. Ф. 251. Оп. 2. Спр. 51. Арк. 4-5.

40. ДАМО. Ф. 251. Оп. 2. Спр. 54. Арк. 4-5.

41. ДАМО. Ф. 251. Оп. 2. Спр. 55. Арк. 5.

42. ДАМО. Ф. 251. Оп. 2. Спр. 58. Арк. 20-21. 
43. ДАМО. Ф. 251. Оп. 2. Спр. 50. Арк. 5-6.

44. ДАМО. Ф. 229. Оп. 4. Спр. 554. Арк. 1-5.

45. ДАМО. Ф. П-1817. Оп. 2. Спр. 273. Арк. 30-32.

46. ДАМО. Ф. П-1817. Оп. 2. Спр. 147. Арк. 3-4.

\section{References}

1. Gernet, M. N. (1951-1954). Istoriya carskoj tyurmy. V 5-ti t. Moskva. [in Russian].

2. Guzenko, Yu. (2006). Stanovlennya i diyalnist gromadskih blagodijnih ob'yednan na Pivdni Ukrayini $v$ drugij polovini XIX - na pochatku XX st. (na materialah Hersonskoyi guberniyi). Mikolayiv: Ilion [in Ukrainian].

3. Shukin, V. (2012). Obshestvennaya blagotvoritelnost i popechitelstvo v penitenciarnyh uchrezhdeniyah Rossijskoj imperii. Naukovi praci Nacionalnogo universitetu "Odeska yuridichna akademiya», 11, 456-463 [in Ukrainian].

4. Melnik, M. Diyalnist Mikolayivskogo pikluvalnogo pro v'yaznici komitetu. URL: http//:www.mk.archives.gov.ua (data zvernennya: 30.05.2019) [in Ukrainian].

5. Palchenkova, V. M. (2013) Transformaciya gromadskogo kontrolyu za vikonannyam pokaran: istoriko-pravovij analiz. Zaporizhzhya: Akcent [in Ukrainian].

6. Palchenkova, V. M. (2014). Vitoki ta evolyuciya gromadskogo kontrolyu za penitenciarnoyu sistemoyu Ukrayini (IX - pochatok XXI st.). (Avtoref. dis. ... d-ra yurid. nauk). Klasich. privat. un-t. Zaporizhzhya [in Ukrainian].

7. Palchenkova, V. M. (2012). Transformaciya pravovoyi reglamentaciyi diyalnosti Tovaristva pikluvalnogo pro tyurmi (1819-1919 rr.) Naukovij visnik Dnipropetrovskogo derzhavnogo universitetu vnutrishnih sprav, 4, 73-82 [in Ukrainian].

8. Palchenkova, V. M. (2013). Ideya ta praktika tyuremnogo patronazhu v Rosijskij imperiyi. Derzhava ta regioni. Seriya: Pravo, 1, 29-33 [in Ukrainian].

9. Palchenkova, V. M. (2012). Chernigivskij komitet tovaristva pikluvalnogo pro tyurmi: osnovni formi, metodi ta zmist diyalnosti. Derzhava ta regioni. Seriya: Pravo, 2, 188193 [in Ukrainian].

10. Cerenyuk, O. M. (2002) Rol komitetiv Tovaristva pikluvalnogo pro tyurmi u rozvitku penitenciarnoyi sistemi Naddnipryanskoyi Ukrayini XIX st. Problemi istoriyi Ukrayini XIX - pochatku XX st., 5, 169-183 [in Ukrainian].

11. Shebalkov, S. V. (2014). Tyurma v Rossii v konce XIX - nachale XX veka i ee ispravitelnoe znachenie. Uchenye zapiski Kazanskogo universiteta: gumanitarnye nauki. Kn. 3. T. 156, 111-120 [in Ukrainian].

L. Levchenko, Doctor of Historical Science, Associate Professor, Director of the State Archives of Mykolayiv region

e-mail: loralewch@gmail.com; ORCID ID: 0000-0001-9097-7373

The Mykolayiv Committee of trustees over prisons as a body
of prison economy management and trusteeship of prisoners

The history of the Committee of trustees over prisons on the territory of Ukraine, controlled by the Russian Empire, in the 19th - at the beginning of the 20th century, is up-to-date at the current stage of the penitentiary system reforms in Ukraine, when it is needed to establish the public control over penitentiary institutions and to develop the transparency of their activities. Unfortunately, there 
are not a lot of scientific works devoted to the problem. Therefore, the purpose of this article is to discover the activity of the Mykolayiv Committee of trustees over prisons and its role and the actual influence on the situation in the Mykolayiv prisons. The activity of the Mykolayiv Committee of trustees over prisons, despite its shortcomings, generally had a positive impact on the situation in the prison institutions in Mykolayiv. In fact, the Committee supported people in prisons, reminding them that they were still members of the community. The church, school, library, teaching, reading, working together in the garden, in workshops and outside prisons, in the city, at least contributed a little to socialization of prisoners and maintained their connection with the outside world to which they were to return. The state, pushing the prisons to be at almost full self-financing, prompted the prison administration to use forced labor. Money earned by prisoners were directed to provide of prisons and to give financial support for prison officials. And yet, any work contributed to re-education. Unlikely prisoners were to be seating without work and waiting for charity. While working, they made a little money for their living as well. However, the prison administrators abused their official position. Using low-cost prisoners' labor, it turned prisons into commercial enterprises with forced labor. In this way, the prison superiors nullified the Committee's efforts in the sphere of prisoners' rehabilitation and hampered the humanization of the Russian Empire penitentiary system.

Keywords: the Mykolayiv Committee of trustees over prisons; Mykolayiv prison; Mykolaiv city prison; Mykolaiv correctional detention unit. 